\title{
IDENTIFIKASI TINGKAT PENGETAHUAN IBU MENYUSUI TENTANG UPAYA UNTUK MENINGKATKAN KESEHATAN DAN PRODUKSI ASI SELAMA PANDEMI
}

\author{
Yuni Puji Widiastuti ${ }^{1}$, Esti Mediastini ${ }^{2}$, Siti Musyarofah ${ }^{3}$ \\ ${ }^{1}$ PSIK STIKES Kendal \\ ${ }^{2}$ Prodi Farmasi STIKES Kendal \\ ${ }^{3}$ PSKM STIKES Kendal \\ Email: widi ardana@yahoo.com
}

\begin{abstract}
ABSTRAK
Air susu ibu merupakan nutrisi terbaik untuk bayi namun tidak semua ibu mampu memberikan ASI Eksklusive kepada bayinya. Pembatasan sosial selama pandemi virus corona (COVID-19) menimbulkan kekhawatiran dan stres bagi banyak orang tak terkecuali ibu menyusui. Selain itu adanya ancaman penularan virus membuat ibu merasa tidak nyaman dan stress sehingga berpengaruh terhadap kondisi kesehatan dan produksi ASI. Kurangnya pengetahuan ibu dan keluarga tentang upaya peningkatan kesehatan dan produksi ASI dimasa pandemic merupakan masalah mendasar yang dapat berpengaruh terhadap keberhasilan pemberian ASI Eksklusive yang berdampak terhadap kesehatan ibu dan bayi serta tumbuh kembang bayi disaat ini maupun dimasa mendatang. Penelitian ini bertujuan untuk mengidentifikasi tingkat pengetahuan ibu menyusui tentang upaya untuk menigkatkan kesehatan dan produksi ASI di masa pandemi. Desain penelitian ini adalah penelitian deskriptif dengan pendekatan crossectional. Samppel sebanyak 57 responden yang diambil dengan tehnik concecutive sampling. Analisis data menggunakan statistic deskriptif yang menampilkan frekwensi dan persentase. Hasil penelitian menunjukkan bahwa hamper keseluruhan responden memiliki tingkat pengetahuan baik tentang upaya untuk mneingkatkan kesehatan yaitu sebanyak 46 responden $(80,7 \%)$ dan hamper keseluruhan responden memiliki tingkat pengetahuan yang baikntentang upaya meningkatkan produksi ASI yaitu sebanyak 48 responden $(84,2 \%)$. Simpulan dari penelitian ini adalah tingkat pengetahuan ibu menyusui tentang upaya untuk meningkatkan kesehatan dan produksi ASI berada pada kategori Baik.
\end{abstract}

Kata Kunci: Ibu menyusui, produksi ASI, tingkat pengetahuan, upaya untuk meningkatkan kesehatan,

\begin{abstract}
Breastmilk is the best nutrition for babies but not all mothers are able to give exclusive breastfeeding to their babies. Social restrictions during the coronavirus (COVID-19) pandemic cause worry and stress for many people, including breastfeeding mothers. In addition, the threat of virus transmission makes mothers feel uncomfortable and stressed full and so that it affects health conditions and breastmilk production. Lack of knowledge of mothers and families about efforts to improve health and breastmilk production during a pandemic is a fundamental problem that can affect the success of exclusive breastfeeding which has an impact on the health of mothers and babies and the growth and development of babies now and in the future. This study aims to identify the level of knowledge of breastfeeding mothers about efforts to improve health and milk production during the pandemic. The
\end{abstract}


design of this research is descriptive research with a cross-sectional approach. A sample of 57 respondents was taken using a consecutive sampling technique. Data analysis uses descriptive statistics that display the frequency and percentage. The results showed that almost all respondents had a good level of knowledge about efforts to improve health, as many as 46 respondents (80.7\%) and almost all respondents had a good level of knowledge about efforts to increase breast milk production, as many as 48 respondents (84.2\%). The conclusion of this study is that the level of knowledge of breastfeeding mothers about efforts to improve health and milk production is in the Good category.

Keywords: Breastfeeding mothers, breastmilk production, level of knowledge, efforts to improve health

\section{LATAR BELAKANG}

Air susu ibu (ASI) adalah makanan alami yang diproduksi dan diberikan oleh ibu khusus untuk bayinya. ASI merupakan makanan dengan nutrisi terbaik untuk bayi terutama bayi usia 0-6 bulan yang fungsinya tidak dapat tergantikan oleh makanan dan minuman apapun. Hal ini dikarenakan ASI steril dan tidak terkontaminasi serta mengandung unsur zat gizi yang sempurna untuk mendukung pertumbuhan dan perkembangan bayi. WHO dan UNICEF (2020) merekomendasikan selama pandemi sebaiknya bayi tetap hanya diberi ASI eksklusive selama 6 bulan dan pemberian ASI dilanjutkan sampai anak berumur minimal dua tahun. Pemberian ASI merupakan pemenuhan hak bagi setiap ibu dan anak serta investasi terbaik untuk meningkatkan kesehatan, perkembangan mental social anak dan bangsa (Kemkes RI, 2019).

Beberapa penelitian menunjukkan bahwa anak yang mendapatkan ASI Eksklusif dan pola asuh yang tepat akan tumbuh dan berkembang secara optimal dan tidak mudah sakit. Selain itu, pemberian ASI mampu mempererat ikatan emosional antara ibu dan bayi sehingga diharapkan akan tumbuh dan berkembang menjadi anak dengan ketahanan pribadi yang kuat dan mampu mandiri (Roesli, 2010). Namun pada kenyataannya tidak semua ibu mampu memberikan ASI terutama ASI Eksklusive kepada bayinya. Hal ini tercermin dari rendahnya angka cakupan ASI eksklusif.

Menurut Riskesdas (2018) Angka cakupan ASI beberapa negara di ASIA tenggara tidak jauh berbeda. Sebagai gambaran bahwa angka cakupan ASI Eksklusive di Myanmar 24\%, Vietnam 27\%, Philippines 34\%, India mencapai 46\% dan di Indonesia Angka cakupan ASI ekslusif lebih tinggi dibandingkan angka global yaitu $48 \%$ namun masih jauh dari target naisional yaitu 80\% (Kemkes RI, 2019). Sedangkan Cakupan ASI eksklusive di Jawa tengah mencapai 54,4\% dan di Kabupaten Kendal mencapai 46\% (Dinkes Provinsi Jateng, 2018). Rendahnya Cakupan ASI eksklusif tidak lepas dari masalah yang terjadi selama proses menyusui diantaranya adanya kepercayaan yang tidak benar yaitu tentang kurangnya produksi atau ASI keluar sedikit sehingga tidak mencukupi kebutuhan bayi. Kurangnya produksi ASI ini dapat dipengaruhi oleh beberapa faktor diantaranya adalah kondisi kesehatan fisik dan psikologis ibu, makanan dan minuman yang dikonsumsi oleh ibu, pengetahuan ibu tentang menyuui, isapan bayi (Bobak, Lowdermilk, Jensen, 2013).

Permasalahan terkait rendahnya pencapaian cakupan ASI Eksklusif juga disebabkan beberapa hal, pertama gencarnya pemasaran susu formula. Kedua, perusahaan yang mempekerjakan perempuan tidak memberi kesempatan bagi ibu yang memiliki bayi 0-6 bulan untuk melaksanakan pemberian ASI secara eksklusif, hal ini terbukti dengan belum 
tersedianya ruang laktasi dan perangkat pendukungnya. Ketiga, masih banyak tenaga kesehatan ditingkat layanan yang belum peduli atau belum berpihak pada pemenuhan hak ibu memberikan ASI dan bayi untuk mendapatkan ASI Eksklusif. Keempat, Masih sangat terbatasnya tenaga konselor ASI. Kelima, belum maksimalnya kegiatan komunikasi informasi dan edukasi, sosialisasi, advokasi, dan kampanye terkait pemberian ASI, dan belum semua rumah sakit melaksanakan 10 Langkah Menuju Keberhasilan Menyusui (Dinkes Provinsi Jateng, 2018).

Selain masalah diatas, beberapa factor yang mempengaruhi rendahnya pemberian ASI eksklusif di Kabupaten Kendal diantaranya adalah kurangnya pengetahuan ibu, kondisi kesehatan fisik, mental dan social ibu, kelancaran produksi ASI, konseling dan dukungan menyusui, factor pemberian ASI, nutrisi, inisiasi menyusu dini dan perawatan payudara (Dinkes Kabupaten Kendal, 2016). Kurangnya pengetahuan Ibu tentang proses menyusui dan pentingnya ASI serta kondisi kesehatan fisik, mental psikososial menimbulkan beberapa masalah selama menyusui dan berdampak terhadap ketidakmampuan ibu untuk memberikan ASI Eksklusif. Masalah ini terutama terjadi pada ibu yang baru pertama menyusui karena belum memiliki pengalaman menyusui sebelumnya.

Hal ini diperburuk dengan kondisi saat ini. Pandemi Covid-19 kunjungan ibu hamil secara fisik sehingga layanan konseling laktasi sebelum melahirkan sebagai salah satu kunci kesuksesan menyusui menjadi terhambat. Belum lagi ibu melahirkan yang terkonfirmasi positif Covid-19 tidak boleh melakukan Inisiasi Menyusu Dini dan proses pemberian ASI tertunda, pembatasan social selama pandemic mennimbulkan kecemasan dan stress pada terutama pada ibu menyusui sehingga berdampak terhadap kesehatan dan produksi ASI sehingga menurunkan tingkat keberhasilan pemberian ASI eksklusif dan berdampak terhadap pertumbuhan perkembangan bayi dan balita serta berkontribusi untuk terjadinya kekurangan gizi dan stunting (Unicef, 2020; WHO' 2020). Oleh karena itu pengetahuan ibu tentang upaya peningkatan kesehatan dan produksi ASI merupakan hal mendasar yang sangat penting sebagai upaya untuk meningkatkan keberhasilan pemberian ASI eksklusif selama pandemi. Penelitian ini bertujuan untuk mengidentifikasi tingkat pengetahuan ibu menyusui tentang upaya meningkatkan kesehatan dan produksi ASI selama pandemi.

\section{METODE PENELITIAN}

Desain penelitian merupakan bentuk rancangan yang digunakan dalam melakukan prosedur penelitian (Alimul, 2007). Penelitian ini merupakan Deskriptif dengan pendekatan Crosssectional. Populasi penelitian ini adalah ibu menyusui yang berada di wilayah Dinas Kesehatan Kabupaten Kendal. Sampel dalam penelitian ini sejumlah 57 responden yang diambil dengan teknik convinience sampling, yaitu subjek yang memenuhi kriteria inklusi diambil sebagai sampel. Kriteria inklusi sampel sebagai berikut: 1) Ibu menyusui yang menyusui bayi 0-12 bulan 2) Ibu menyusui yang meu menjadi responden. Penelitian dilaksanakan di Puskesmas Kaliwungu, Puskesmas Cepiring dan Puskesmas Rowosari I di Wilayah kerja Dinas Kesehatan Kabupaten Kendal. Penelitian ini dilaksanakan pada bulan januari sampai dengan bulan Oktober 2021. Pengumpulan data menggunakan kuesioner yang terdiri dari kuesioner karakteristik responden, kuesioner pengetahuan tentang upaya untuk meningkatkan kesehatan dan kuesioner tentang upaya untuk meningkatkan produksi ASI. Analisis statistik univariat menggunakan Statistik Deskriptif yang menampilkan frekwensi dan persentase. 
HASIL DAN PEMBAHASAN

1. Karakteristik Responden

Tabel 1 Karakteristik Responden

\begin{tabular}{lccc}
\hline \multicolumn{1}{c}{ Karakteristik } & & Frekuensi & Presentase \\
\hline Usia & Reproduktif & 45 & $78,9 \%$ \\
& Resiko & 12 & $21,1 \%$ \\
& Reproduksi & & \\
& & 57 & $100 \%$ \\
\hline Pendidikan & Rendah & 18 & $68,4 \%$ \\
& Tinggi & 39 & $31,6 \%$ \\
& & & $100 \%$ \\
\hline Pekerjaan & & 57 & $63,2 \%$ \\
& Bekerja & 33 & $26,8 \%$ \\
& Tidak Bekerja & 24 & $100 \%$ \\
\hline Penghasilan & & 57 & $57,9 \%$ \\
& & 36 & $42,1 \%$ \\
& < UMK & 21 & $100 \%$ \\
\hline
\end{tabular}

2. Tingkat Pengetahuan Ibu Menyusui tentang Upaya untuk Meningkatkan Kesehatan

Tabel 2 Distribusi Responden berdasarkan Tingkat Pengetahuan tentang Upaya meningkatkan Kesehatan $(\mathrm{n}=57)$

\begin{tabular}{|c|c|c|}
\hline Pengetahuan & Frekuensi & Presentase \\
\hline Kurang Baik & 8 & 14,1 \\
\hline Baik & 49 & 85,9 \\
\hline Total & 57 & $100,0 \%$ \\
\hline
\end{tabular}

3. Tingkat Pengetahuan Ibu Menyususi tentang Upaya untuk Meningkatkan Produksi ASI.

Tabel 3 Distribusi Responden berdasarkan Tingkat Pengetahuan tentang Upaya meningkatkan Produksi ASI $(n=57)$

\begin{tabular}{|c|c|c|}
\hline Pengetahuan & Frekuensi & Presentase \\
\hline Kurang Baik & 9 & 15,8 \\
\hline Baik & 48 & 84,2 \\
\hline Total & 57 & $100,0 \%$ \\
\hline
\end{tabular}

Tabel 1 Menunjukkan bahwa sebagian besar reponden berada pada umur reproduksi yaitu sebanyak 45 responden $(78,9 \%)$, sebagian besar responden dengan tingkat pendidikan tinggi yaitu sebanyak 39 responden $(68,4 \%)$, sebagian besar responden memiliki penghasilan $<$ UMK sebanyak 36 responden (63,2\%), sebagian besar responden bekerja yaitu sejumlah 33 responden $(57,9 \%)$. 
Hasil penelitian ini menunjukan bahwa mayoritas usia responden berada pada rentang usia reproduktif. Ibu menyusui yang berada pada usia reproduksi sehat yang membuat ibu mampu untuk berfikir rasional dibandingkan ibu yang usianya digolongkan sebagai usia resiko bereproduksi. Ibu yang berfikir rasional memiliki semangat dan motivasi lebih tinggi dalam upaya untuk mencari informasi terkait. Hal ini sejalan dengan penelitian Qomar (2020) bahwa usia seseorang dapat mempengaruhi pola pikir orang tersebut.

Hal ini juga senada dengan penelitian Handayani, dkk (2020) yang menemukan bahwa usia merupakan salah satu faktor yang dapat menggambarkan kematangan seseorang baik secara fisik, psikis maupun sosial. Semakin bertambahnya usia seseorang maka bertambah pula pengetahuan yang didapat. Semakin dewasa usia seseorang semakin banyak informasi yang dimiliki sehingga membantu ibu untuk tetap sehat saat menyusui (Isnaeni,2013). Berdasarkan dari hasil penelitian, teori dan penelitian sebelumnya, peneliti berpendapat bahwa faktor usia dimana usia mempengaruhi daya tangkap dan pola pikir seseorang, semakin bertambah usia maka akan semakin berkembang pula daya tangkap dan pola pikirnya.

Hasil penelitian menunjukkan data bahwa mayoritas pendidikan ibu menyusui adalah SMA dan PT sejumlah 39 responden $(68,4 \%)$. Hal ini sejalan dengan penelitian Siregar (2020) menemukan bahwa pendidikan merupakan factor yang mempengaruhi pengetahuan dan pemahaman seseorang. Hal ini senada dengan penelitian yang dilakukan oleh Fredika (2015) yang menyatakan bahwa ada hubungan yang signifikan antara tingkat pendidikan dengan pengetahuan seseorang. Tingkat pendidikan seseorang dapat mempengaruhi pengetahuan dan sikap seseorang dalam melakukan sesuatu. Terdapat perbedaan pengetahuan dan sikap antara seseorang yang memiliki tingkat pendidikan rendah dan tingkat pendidikan tinggi.

Penelitian ini sejalan dengan Mubarak (2014) yang menyatakan bahwa pendidikan mempengaruhi proses belajar, semakin tinggi pendidikan seseorang maka semakin mudah untuk menerima informasi. Selain itu Setyorini dan Wulandari (2017) menyebutkan bahwa semakin tinggi pendidikan seseorang maka seseorang tersebut semakin berusaha mememiliki lebih banyak wawasan, sedangkan seseorang dengan tingkat pendidikan yang rendah akses terhadap informasi terkait dengan kesehatan lebih rendah sehingga terkadang tidak mengetahui situasi dan perkembangan yang terjadi di dunia saat ini terkait dengan kesehatan. Berdasarkan hasil penelitian, teori dan penelitian sebelumnya peneliti berpendapat bahwa pendidikan dapat mempengaruhi pengetahuan seseorang, dimana semakin tinggi tingkat pendidikan seseorang maka diharapkan semakin tinggi tingkat pengetahuannya.

Hasil penelitian menunjukkan baha mayoritas ibu menyusui bekerja. Ibu yang bekerja di luar rumah seperti buruh, pegawai kantor, dll memiliki peluang untuk mendapatkan informasi yang terbaru dan adanya diskusi mengenai informasi tersebut dengan teman-temannya. Dibandingkan dengan ibu yang tidak bekerja dan hanya tinggal di rumah yang memiliki pengalaman/penerimaan informasi hanya dari anggota keluarga serumah, dan tetangga. Hal ini memberikan akses yang terbatas dalam penerimaan informasi terbaru.

Hasil penelitian ini didapatkan data bahwa mayoritas ibu dengan pendapatan < UMR sebanyak 36 responden (63,2\%). Penelitian ini sejalan dengan penelitian Hanifah (2019) bahwa faktor yang yang berhubungan dengan pengetahuan seseorang adalah penghasilan atau sosial ekonomi, yang didukung oleh penelitian dengan hasil Hubungan yang paling dominan pada kanker leher rahim dengan deteksi dini kanker leher rahim di wilayah kecamatan Gisting kabupaten Tanggamus Lampung tahun2016 adalah status ekonomi dengan p-value < 0,001 ; OR 6,8.

Penelitian ini sejalan dengan teori Fariza (2013) bahwa Status sosial ekonomi adalah kedudukan atau posisi seseorang dalam masyarakat. Status sosial ekonomi adalah gambaran tentang keadaan seseorang atau suatu masyarakat yang ditinjau dari segi sosial ekonomi, 
gambaran itu seperti tingkat pendidikan, pendapatan dan sebagainya. Status ekonomi kemungkinan besar merupakan pembentuk gaya hidup keluarga. Pendapatan keluarga memadai akan menunjang pengetahuan seseorang. Status sosial ekonomi yang baik akan sangat mendukung kehidupan seseorang atau keluarga untuk menerapkan kehidupan yang lebih baik, dimana status soaial ekonomi yang baik maka akan menunjang pengetahuan sesorang menjadi baik pula, sedangkan penghasilan yang kurang maka akan mengakibatkan pengetahuan sesorang menjadi kurang. Berdasarkan hasil penelitian, teori dan penelitian sebelumnya peneliti berpendapat bahwa status sosial ekonomi yang baik akan sangat mendukung kehidupan seseorang agar lebih baik.

Hasil penelitian menunjukkan bahwa sebagian besar responden memiliki tigkat pengetahuan baik tentang upaya untuk meningkatkan kesehatan selama pandemic yaitu sejumlah 49 responden $(85,9 \%)$. Sama halnya dengan hasil penelitian tentang upaya untuk meningkatkan produksi ASI berada pada kategori baik yaitu sebanyak 48 responden $(84,2 \%)$. Hal ini dapat dilihat secara rinci pada table 2 dan 3.

Pengetahuan adalah segala sesuatu yang diketahui berdasarkan pengalaman manusia itu sendiri dan pengetahuan akan bertambah sesuai dengan proses pengalaman yang dialaminya (Mubarak, 2011). Pengetahuan merupakan hasil dari tahu dan ini terjadi setelah seseorang melakukan penginderaan terhadap suatu objek. Penginderaan terjadi melalui pancaindera manusia yakni, indera pendengaran, penglihatan, penciuman, perasaan dan perabaan. Sebagian pengetahuan manusia didapat melalui mata dan telinga (Notoatmodjo, 2012).

Hasil penelitian ini sejalan dengan penelitian Aritonang (2020) bahwa pengetahuan merupakan hal yang terpenting dalam menentukan tindakan ataupun perilaku seseorang, jika seseorang berpengetahuan baik tentang sesuatu maka dominan memiliki sikap dan tindakan yang baik juga. Adanya pandemi COVID-19 ini memaksa ibu menyusui untuk banyak mencari tahu tentang penyakit ini dan upaya untuk meningkatkan kesehatan serta produksi ASI sebagai langkah untuk pencegahan dan meningkatkan stamina agar tetap sehat serta tetap mampu menyusui selama pandemi.

Pengetahuan adalah salah satu hal yang penting diperhatikan terutama selama pandemic dalam rangka penanganan kasus COVID-19. Pengetahuan masyarakat khususnya dalam meningkatkan kesehatan dan mencegah transmisi penyebaran virus SARS-CoV-2 sangat berguna dalam menekan penularan virus tersebut (Law, Leung, \& Xu, 2020). Dengan memiliki pengetahuan yang baik terhadap suatu hal, seseorang akan memiliki kemampuan untuk menentukan dan mengambil keputusan bagaimana ia dapat menghadapinya (Purnamasari, Ika; Raharyani, 2020).

Responden dalam penelitian ini sebagian besar memiliki pengetahuan baik tentang upaya untuk meningkatkan kesehatan dan produksi ASI. Hal ini dipengaruhi oleh factor usia, pendidikan dan pekerjaan. Dimana sebagian besar dari responden berada pada rentang usia reproduksi sehat, berpendidikan SMA dan PT serta bekerja. Usia merupakan salah satu faktor yang merefleksikan tingkat kematangan seseorang baik secara fisik, psikis maupun sosial. Semakin bertambah usia seseorang maka bertambah pula pengetahuan dan pengalaman yang didapat. Semakin dewasa usia seseorang semakin banyak informasi yang dimiliki sehingga ibu memiliki pengetahuan yang baik terkait upaya untuk meningkatkan kesehatan dan produksi ASI dan membantu ibu untuk tetap sehat saat menyusui dimasa pandemic.

Ibu menyusui yang memiliki pendidikan tinggi dan bekerja, hal ini mempengaruhi pengetahuan, pemahaman dan pengalaman seseorang. Semakin tinggi pendidikan Ibu menyusui maka semakin baik pengetahuan dan pemahaman ibu menyusui tentang upaya untuk meningkatkan kesehatan dan produksi ASI. Menurut Riyanto (2013) bahwa 
pengetahuan sangat erat kaitannya dengan pendidikan di mana diharapkan seseorang dengan pendidikan tinggi, maka orang tersebut akan semakin luas pula pengetahuannya.. Menurut Olum dkk (2020) menyatakan bahwa pendidikan professional berkelanjutan diperlukan untuk meningkatkan pengetahuan dan mengubah sikap negatif serta meningkatkan praktik pencegahan dan pengobatan yang lebih baik lagi.

Sebagian besar responden adalah ibu bekerja, hal ini memberikan kesempatan pada ibu untuk bisa lebih banyak bersosialisasi dan berdiskusi dengan orang lain. Ibu yang bekerja bisa sharring dan curah pendapat dengan teman-temannya terkait upaya untuk meningkatkan kesehatan dan produksi ASI selama pandemi. Dengan demikian ibu yang bekerja di luar rumah memiliki peluang untuk mendapatkan informasi yang terbaru tentang hal ini. Ibrahim et al , Ibu yang bekerja memiliki pengetahuan manajemen laktasi yang lebih baik dibandingkan dengan ibu yang tidak bekerja dikarenakan pada ibu bekerja lebih mudah untuk mengakses informasi - informasi yang berkaitan dengan u[aya untuk meningkatkan produksi ASi sehingg mampu memberikan ASI eksklusif. Lingkungan pekerjaan dapat menjadikan seseorang memperoleh pengalaman dan pengetahuan baik secara langsung maupun tidak langsung, pengalaman yang juga menjadi bagian yang dapat mempengaruhi tingkat pengetahuan.

\section{SIMPULAN DAN SARAN \\ Simpulan}

Adapun simpulan dari penelitian ini adalah sebagai berikut:.

1. Gambaran karakteristik responden dalam penelitian ini yaitu sebagian besar responden adalah Usia reproduktif, pendidikan SMA dan PT, bekerja dan penghasilan kurang dari UMK.

2. Sebagian besar tingkat pengetahuan tentang upaya untuk meningkatkan kesehatan di masa pandemi adalah baik yaitu sebanyak 49 Reponden $(85,9 \%)$

3. Sebagian besar tingkat pengetahuan tentang upaya untuk meningkatkan produksi ASI di masa pandemi adalah baik yaitu sebanyak 48 Reponden $(84,2 \%)$

\section{Saran}

Berdasarkan hasil dan simpulan ada beberapa saran yang ditujukan kepada responden, pemerintah. Diharapkan responden untuk selalu mencari informasi yang akurat terkait upaya untuk meningkatkan kesehatan dan produksi ASI dimasa pandemic pada sumber yang dapat dipertanggung jawabkan. Pemerintah dalam hal ini Puskesmas agar memberikan komunikasi informasi dan edukasi secara berkelanjutan dalam rangka meningkatkan pengetahuan masyarakat sehingga seluruh masyarakat memiliki pengetahuan yang benar tentang hal ini.

\section{UCAPAN TERIMAKASIH}

Ucapan terima kasih kami haturkan kepada DIKTI yang telah mensupport dan membiayai penelitian ini. Terima kasih juga kami haturkan kepada responden atas peran serta aktifnya dalam penelitian ini. Ucapan terima kasih juga kami haturkan kepada Kepala Puskesmas Cepiring dan Kaliwungu serta Sekolah tinggi Ilmu kesehatan Kendal yang telah memfasilitasi pelaksanaan kegiatan penelitian ini. Tak lupa terkhusus tim penelitian yang luar biasa, terima kasih atas kerjasama yang indah dan penuh semangat. 


\section{DAFTAR PUSTAKA}

Albertina, Meity. (2015). Hubungan Pijat Oksitosin Dengan Kelancaran Produksi ASI Pada Ibu Post Partum Seksio Sesarea Hari Ke 2 - 3. Poltekkes Kemenkes Kaltim: Jurnal Husada Mahakam.

Aritonang, J., Nugraeny, L., Sumiatik, \& Siregar, R. N. (2020). Peningkatan Pemahaman Kesehatan pada Ibu hamil dalam Upaya Pencegahan COVID-19. Jurnal SOLMA, 9(2), 261-269. https://doi.org/10.22236/solma.v9i2.5522

Azizah. Imroatul (2017). Pengaruh Pijat Oksitosin Terhadap Pengeluaran ASI Pada Ibu Postpartum Di Bpm Pipin Heriyanti Yogyakarta Tahun 2016. Yogyakarta: Media Ilmu Kesehatan

Bobak dan Lowdermilk. (2005). Buku Ajar Keperawatan Maternitas. Jakarta. EGC

Departemen Kesehatan RI. (2007). Pedoman Strategi KIE Keluarga Sadar Gizi (KADARZI). Direktorat Jenderal Bina Kesehatan Masyarakat, Direktorat Bina Gizi Masyarakat

Dinkes Kendal. (2019). Cakupan Pemberian ASI Eksklusif di Kabupaten Kendal. Kendal: Dinkes Kab Kendal

Handayani N. 2019. Upaya Meningkatkan Produksi ASI pada Ibu Menyusui. https://duta.co/upaya-meningkatkan-produksi-asi-pada-ibu-menyusui

Haryono, \& Setianingsih. (2013). Manfaat ASI Eksklusif untuk Buah Hati Anda. Yogyakarta: Gosyen Publishing

Jateng Dinkes. (2018). Profil Kesehatan Provinsi Jawa Tengah. Jateng: Dinkes Jateng.

Kemenkes RI. (2019). Profil Kesehatan Indonesia Tahun 2018. Jakarta: Kementrian Kesehatan Republik Indonesia.

Kodrat, Laksono. (2010). Dahsyatnya ASI \& Laktasi. Yogyakarta: Media Baca

Laksono, K. (2010). Dahsyatnya ASI \& Laktasi. Yogyakarta: Media Baca.

Lestari EV. 2020. Cara Meningkatkan Produksi ASI secara ALami dengan Cepat. https://www.cekaja.com/info/cara-meningkatkan-produksi-asi

Mardiningsih, Eko. (2010). Efektifitas kombinasi teknik marmet dan pijat oxytocin terhadap produksi ASI ibu post section caesaria di wilayah rumah sakit wilayah jawa tengah. Tesis. Universitas Indonesia: Jakarta.

Marmi. (2012). ASI Saja Mama. Yogyakarta: Pustaka Pelajar.

Maryunani, A. (2012). Inisiasi Menyusu Dini, ASI Eksklusif dan Manajemen Laktasi. Jakarta: TIM.

Muhammad RA. 2019. Pola Makan Sehat dan Bergizi untuk Meningkatkan Imunitas Saat Terserang Covid-19. UNS. https://uns.ac.id/id/uns-opinion/pola-makan-sehat-danbergizi-untuk-meningkatkan-imunitas-saat-terserang-covid-19.html

Notoatmodjo, Soekidjo. (2012). Metodologi Penelitian Kesehatan. Jakarta : Rineka Cipta

Notoatmodjo, Soekidjo. (2014). Promosi Kesehatan dan Perilaku Kesehatan. Jakarta : Rineka Jaya

Nursalam. (2013). Metodologi Penelitian Ilmu Keperawatan. Jakarta: Salemba Medika.

Noya BL. (2019). Terapkan Manajemen Laktasi untuk Memastikan Kelancaran Menyusui. https://www.alodokter.com/terapkan-manajemen-laktasi-guna-memastikankelancaran-menyusui.

Purnamasari, Ika; Raharyani, A. E. (2020). Tingkat Pengetahuan Dan Perilaku Masyarakat Kabupaten Wonosobo Tentang Covid-19. Jurnal Ilmiah Kesehatan, 10(1), 33-42. Retrieved from https://ojs.unsiq.ac.id/index.php/jik/artic le/view/1311/783

Roesli. (2012). Inisiasi Menyusui Dini Plus ASI Eksklusif. Pustaka Bunda.

Sugiyono. (2016). Metodologi Penelitian Kuantitatif, Kualitatif dan R\&D. Bandung: Alfabeta. 
Unicef. 2020. Menyusui Pada Masa Wabah Virus Corona. https://www.unicef.org/indonesia/id/stories/menyusui-pada-masa-wabah-viruscorona-covid-19

Unicef Indonesia. (2013). ASI adalah penyelamat hidup paling murah dan efektif di dunia. http://www.unicef.org/indonesia/id.

Wattimena, I., Nathalia, L.S., \& Marsuyanto, Y. (2012). Kekuatan psikologis ibu menyusui. Jurnal Kesehatan Masyarakat Nasional, KesMas, 7(2).

WHO. 2020. Novel Corona Virus. https://www.who.int/indonesia/news/novelcoronavirus/qa-for-public

WHO. (2016). Sustainable Development Global solutions Network (SDGs). Jakarta: United Nation.

Wiji, R.K. (2013). ASI dan Panduan Ibu Menyusui.Yogyakarta: Nuha Medika 